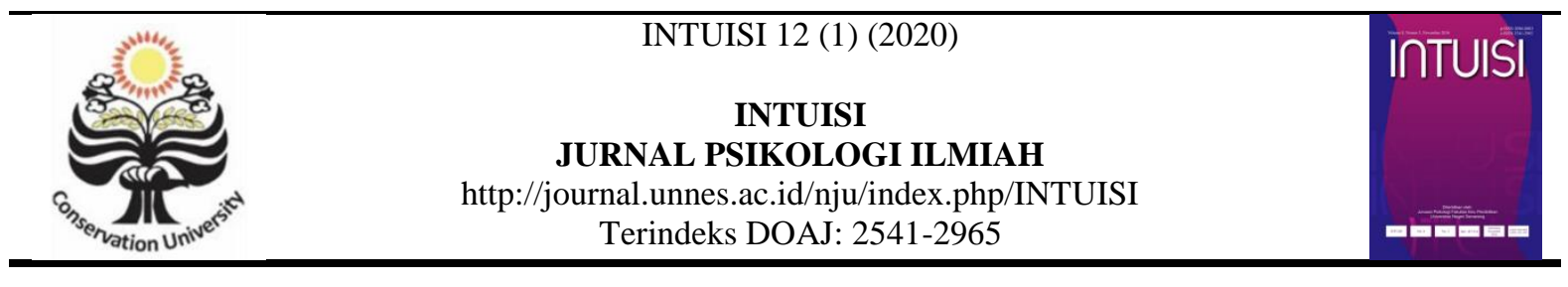

\title{
PELATIHAN STRATEGI KOPING PADA NARAPIDANA REMAJA DI LEMBAGA PEMASYARAKATAN
}

\section{Anak Agung Sri Sanjiwani ${ }^{\bowtie}$, Afif Kurniawan, IGA. Putu Wulan Budisetyani}

Fakultas Psikologi, Universitas Airlangga, Surabaya, Indonesia

\begin{tabular}{l}
\hline Info Artikel \\
\hline Sejarah Artikel: \\
Disubmit 3 Desember 2019 \\
Direvisi 20 Januari 2020 \\
Diterima 24 Maret 2020
\end{tabular}

\section{Keywords:}

Adolescent Inmate,

Stress, Coping

Strategy

\begin{abstract}
Abstrak
Remaja yang terlibat dalam kasus hukum mengalami berbagai tekanan yang dapat menyebabkan kondisi stres. Hasil studi pendahuluan pada narapidana remaja menunjukkan bahwa terdapat empat remaja yang mengalami stres pada tingkat sedang dan berat. Gejala stres ditunjukkan dari kondisi emosi yang mudah marah, tersinggung, gelisah dan kesulitan tidur nyenyak. Kondisi stres belum dapat dihadapi dengan strategi koping yang efektif sehingga ditampilkan dengan cara-cara yang kurang adaptif. Penelitian ini bertujuan untuk mengetahui pengaruh pelatihan strategi koping dalam menurunkan stres yang dialami oleh narapidana remaja. Penelitian ini menggunakan desain one group pretest-postest design dengan teknik purposive sampling. Pengumpulan data dilakukan menggunakan skala stres dari DASS (Depression anxiety stress scale) dengan analisis wilcoxon signed-ranks test. Jumlah subjek dalam penelitian ini adalah empat orang remaja berusia 15-18 tahun. Pemberian lembar kerja dan wawancara individual juga dilakukan guna memperdalam data yang diperoleh. Hasil penelitian ini menunjukkan bahwa tidak terdapat perubahan yang signifikan dari tingkat stres narapidana remaja antara sebelum dan setelah pemberian pelatihan strategi koping $(\mathrm{z}=-0,730 ; \mathrm{p}=0,465, \mathrm{p}>0,05)$, namun berdasarkan lembar kerja dan wawancara individual diketahui bahwa keempat subjek dapat melakukan penilaian ulang (reappraisal) secara positif terhadap situasi yang dialami dan dapat menentukan strategi koping yang efektif untuk diri masing-masing.
\end{abstract}

\begin{abstract}
Adolescents involved in legal cases experience various pressures that can lead to stressful conditions. Preliminary study results in adolescent inmates have shown that there are four adolescents experience stress at moderate and severe levels. Stress symptoms are shown from an emotional condition that is irritable, restless and difficulty to sleep well. The stress conditions can not be solved with effective coping strategies that are showed in less adaptive ways. The aim of the research was to determine the influence of coping strategy training in reducing the stress experienced by adolescent inmates in prison. This research uses one group pretest-postest design with purposive sampling technique. Data were collected using the stress scale of the DASS (Depression Anxiety Stress Scale) and data analysis with wilcoxon signed-ranks test. The number of subjects in this study was four adolescents aged 15-18 years old. The provision of individual worksheets and interviews was also done to deepen the data obtained. The results of this study showed that there were no significant changes in the stress levels of adolescent inmates between before and after providing coping strategy training ( $z=-$ 0,$730 ; p=0,465, p>0.05$ ), but based on worksheets and individual interviews it is known that the four subjects can be positively reappraisal to the situation experienced and can determine an effective coping strategy for each of themselves.
\end{abstract}

(C) 2020 Universitas Negeri Semarang

Alamat korespondensi:

p-ISSN 2086-0803

Fakultas Psikologi, Universitas Airlangga,

e-ISSN 2541-2965

Jl. Ailangga 4-6 Surabaya, Indonesia

srisanjiwani-16@psikologi.unair.ac.id 


\section{PENDAHULUAN}

Masa remaja ditandai dengan perubahan pada aspek fisik, emosi dan kognitif. Pengalaman masa kanak-kanak dan karakteristik biologis bertransformasi menjadi minat, kompetensi, kepercayaan diri dan memulai peran penting sebagai remaja (Lerner \& Steinberg, 2004). Tahun-tahun masa remaja disebutkan menjadi periode terjadinya pergejolakan yang melibatkan perubahan emosional, konflik dalam keluarga, pengasingan dari masyarakat, perilaku tidak peduli serta adanya penolakan terhadap nilai orang dewasa (Papalia, Old, \& Feldman, 2008)

Studi menunjukkan bahwa remaja menjadi kelompok yang rentan mengalami permasalahan terkait emosi dan perilaku (Beauchaine \& Hinshaw, 2013; Wilmshurst, 2015). Selama pada periode ini segala perubahan ataupun transisi yang dialami rentan terhadap sejumlah faktor eksternal serta perubahan fisiologis internal. Banyak remaja menjadi sangat rentan terhadap gejolak emosi yang dapat melibatkan kondisi kecemasan serta perubahan suasana hati. (Siegel \& Welsh, 2018). Permasalahanpermasalahan ini kemudian dikaitkan dengan kenakalan serta perilaku-perilaku antisosial seperti penyalahgunaan narkoba, alkohol, seks bebas, kejahatan di sekolah hingga vandalisme.

Berbagai kenakalan yang dilakukan remaja seringkali melibatkan pelanggaran hukum yang akhirnya menyebabkan hukuman penjara. Shulman dan Cauffman (2012) menyebutkan bahwa dibandingkan dengan narapidana dewasa, narapidana remaja menghadapi situasi penahanan dengan tambahan tekanan yaitu kondisi yang belum matang dalam melewati masa di lapas. Penahanan di penjara juga membuat remaja terpisah dari lingkungan sosial mereka sehingga sangat mempengaruhi kondisi psikologis secara keseluruhan.
Data menunjukkan, hingga Juni 2017 tercatat dalam UPT yang dikelola oleh Direktorat Jenderal Pemasyarakatan bahwa jumlah narapidana usia remaja mencapai 2.559 anak. Jumlah ini mengalami kenaikan dari tahun 2016 yaitu 2.330 anak yang tersebar di seluruh Indonesia. Data tersebut juga menunjukkan bahwa narapidana laki-laki menunjukkan angka yang lebih tinggi daripada narapidana perempuan (Institute for Criminal Justice Reform, 2017).

Berdasarkan studi pendahuluan di sebuah Lembaga Pemasyarakatan (Lapas) di Bali, terdapat 12 orang narapidana remaja laki-laki yang ditempatkan di sebuah blok khusus usia remaja. Narapidana remaja ini nantinya akan di pindahkan ke Lembaga Pemasyarakatan anak ketika sidang vonis telah dilaksanakan. Beberapa remaja juga akan tetap tinggal jika usia mereka saat melakukan pelanggaran adalah 18 tahun. Adapun jenis pelanggaran yang dilakukan mencakup penyalahgunaan narkoba, pelecehan seksual, pencurian dan pembunuhan.

Hasil wawancara menunjukkan kondisi-kondisi yang dialami oleh narapidana remaja. Salah satu napi remaja IF (15 tahun) menyebutkan

“...lama-lama stres saya disini, ga bisa berpikir jernih..."

Meski demikian IF bersyukur hanya terkena dua kasus yaitu penodongan dan pencurian sedangkan terdapat beberapa temannya yang harus mendapat vonis dari tiga kasus kriminal sehingga harus lebih lama berada di dalam Lapas.

Selain itu di ketahui bahwa selama menjalani kehidupan di dalam Lapas, para napi remaja menghadapi berbagai situasi yang memicu munculnya emosi negatif seperti perasaan menyesal yang mendalam, malu atas kejadian yang telah dilakukan, perasaan kecewa terhadap diri serta rasa marah karena teman-teman terdekat mereka tidak mau mengunjungi saat mereka berada di Lapas. 
“...ya kakak ngancem awas kamu ngulang lagi, ga tak anggap sebagai keluarga kamu" - MR (17 tahun)

"...saya malu sama orangtua, selama ini saya dikira anak baik dan rajin sholat" - AN (16 tahun) "...kesel banget sama tementemen ga ada yang kunjungan, dulu saya sering banget lawan ibu dan mentingin temen-temen" - FR (17 tahun)

Berbagai keluhan tersebut kemudian mengkondisikan para napi remaja menjadi lebih mudah marah, tersinggung karena halhal sederhana seperti saat dibangunkan oleh petugas sipir, saat diminta kerja bakti dan merasa gelisah saat tidur, seringkali mereka juga tidak mau mengkonsumsi makanan dari lapas karena menilai makanan tersebut tidak enak kemudian menjadi marah atas keadaan mereka.

Berdasarkan hal tersebut, kuisioner stres dari DASS (Depression, Anxiety, and Stress Scale) diberikan kepada 12 orang narapidana remaja yang telah mendapat putusan vonis dan yang sedang menunggu sidang vonis, hasilnya menunjukkan terdapat 3 remaja berada dalam kategori normal, 5 orang remaja dalam kondisi stres ringan (mild), 2 remaja yang mengalami kondisi stres dalam tingkat sedang (moderate) dan 2 remaja lain mengalami kondisi stres berat (severe). Keempat remaja yang menunjukkan stres pada tingkat sedang dan berat ini merasakan stres yang ditampilkan dari cara mereka yang kurang adaptif dalam menghadapi berbagai persoalan selama di dalam lapas. Adapun berbagai stresor yang mereka hadapi berkaitan dengan terpisah dari orangtua, menunggu waktu sidang dan tetapan vonis, serta akses di dalam lapas yang sangat terbatas sehingga mereka tidak dapat pergi ke blok lain. Hal ini bertujuan untuk mencegah kemungkinan buruk dari interaksi antara narapidana remaja dengan narapidana dewasa.
Stres merupakan suatu rangkaian reaksi dan proses fisiologis yang dihasilkan dari adanya tuntutan yang dinilai individu mengancam kesejahteraan diri dan individu merasa tidak memiliki sumber daya yang memadai untuk dapat menghadapi tuntutan tersebut (Houghton, Godwin, Neck, \& Manz, 2012).

Suatu reaksi stres dipengaruhi dari peran hasil penilaian individu terhadap kejadian atau stimulusnya. Lazarus (2006) menyebutkan dua bentuk utama dari penilaian kognitif terhadap stres yaitu primary appraisal dan secondary appraisal. Primary appraisal menghasilkan suatu penilaian sejauh mana transaksi dengan lingkungan menghasilkan pengaruh terhadap kesejahteraan individu. Apakah hasilnya positif, tidak relevan atau menekan (mengancam). Selanjutnya secondary appraisal melibatkan penilaian terhadap identifikasi kemampuan diri dan sumber koping untuk menghadapi situasi yang dianggap mengancam atau membahayakan kesejahteraan diri.

Pengalaman penahanan dalam penjara menjadi situasi yang sangat memicu stres yang menyangkut kondisi frustrasi terhadap kehilangan kebebasan, otonomi dan berbagai keterbatasan (Porter, 2018; Talik \& Skowronski, 2018). Individu yang berada dalam penjara juga harus terisolasi dari keluarga, kurangnya aktivitas bertujuan, tidak ada privasi, serta minimnya kesempatan untuk mendapatkan suasana tenang (Mansoor, Perwez, Swamy, \& Ramaseshan, 2015).

Keempat remaja ini diduga belum memahami cara-cara untuk melakukan koping yang efektif terhadap stres yang dihadapi, adapun dari hasil studi pendahuluan diketahui bahwa upaya yang selama ini dilakukan adalah memendam perasaan, mengurung diri, dan berusaha mengalihkan dengan bermain kartu. Hanya saja stres yang dirasakan tetap muncul dan cenderung menilai bahwa segala situasi di dalam lapas merupakan ancaman 
sehingga menghasilkan emosi-emosi negatif seperti marah, menyesal, khawatir mengenai kejelasan vonis saat menjalani proses sidang. Faktor-faktor seperti pola stres, durasi, atau tingkat kontrol yang dimiliki menjadi faktor yang dipertimbangkan dalam menentukan efektivitas dari strategi koping (Vitulic \& Prosen, 2015).

Koping merupakan sebuah proses ketika individu mengelola tuntutan dari dirinya dan lingkungan yang dinilai sebagai situasi yang menekan dan mempengaruhi emosi yang dirasakan (Lazarus, 2006).

Strategi koping didefinisikan sebagai suatu mekanisme yang digunakan individu untuk menguasai, mentolerir, dan meminimalkan atau mengurangi suatu dampak buruk dari peristiwa yang menimbulkan stres (Hashemi, Darshori, Sharif, Karimi, \& Zare, 2015). Secara garis besar strategi koping dapat dibagi menjadi dua bagian yaitu problem-focused coping yang mengarahkan individu untuk mencari informasi mengenai apa yang harus dilakukan dan mengelola tindakan dengan tujuan merubah keadaan dari permasalahan yang dihadapi di lingkungan. Sedangkan pada emotion-focused coping dilakukan individu dengan cara meregulasi emosi yang berkaitan dengan situasi penyebab stres. Kedua jenis koping ini dapat menjadi strategi yang efektif (Lazarus, 2006).

Strategi koping yang efektif merupakan strategi yang dapat mengurangi masalah dan mengurangi tekanan emosi yang dirasakan individu (Hashemi et al., 2015), sehingga strategi koping yang tepat dapat menimbulkan suatu hasil yang positif.
Ketidaktepatan dalam pemilihan strategi koping dapat meningkatkan ketegangan individu terhadap masalah yang dihadapi.

Penelitian sebelumnya menunjukkan bahwa remaja membutuhkan adanya pengarahan mengenai strategi koping yang tepat dan efektif karena seringkali remaja khususnya yang terlibat dalam kasus hukum berada pada kondisi distress yang lebih tinggi dan lebih rentan terhadap berbagai permasalahan kesehatan mental (Jones \& Nonas-Barnes, 2017; Shulman \& Cauffman, 2012).

Berdasarkan hal tersebut maka pelatihan koping terhadap stres diperlukan guna membantu keempat remaja untuk menilai ulang mengenai situasi di dalam lapas dan mengupayakan adanya keyakinan mengenai sumber daya dalam diri guna menghadapi berbagai tuntutan yang dirasakan selama menjalani masa tahanan. Tujuan dari penelitian ini adalah mengetahui pengaruh dari pemberian pelatihan strategi koping dalam menurunkan stres pada narapidana remaja.

Manfaat dalam penelitian ini adalah sebagai tulisan ilmiah yang dapat berkontribusi bagi keilmuan psikologi terkait dinamika stres dan bentuk intervensi pada narapidana remaja. Secara praktis, penelitian ini diharapkan dapat membantu narapidana remaja dalam menurunkan stres yang dialami serta membantu menentukan strategi koping yang efektif. Hipotesis yang kemudian akan diuji yaitu terdapat penurunan stres pada narapidana remaja yang signifikan antara sebelum dan setelah diberikan pelatihan strategi koping. 


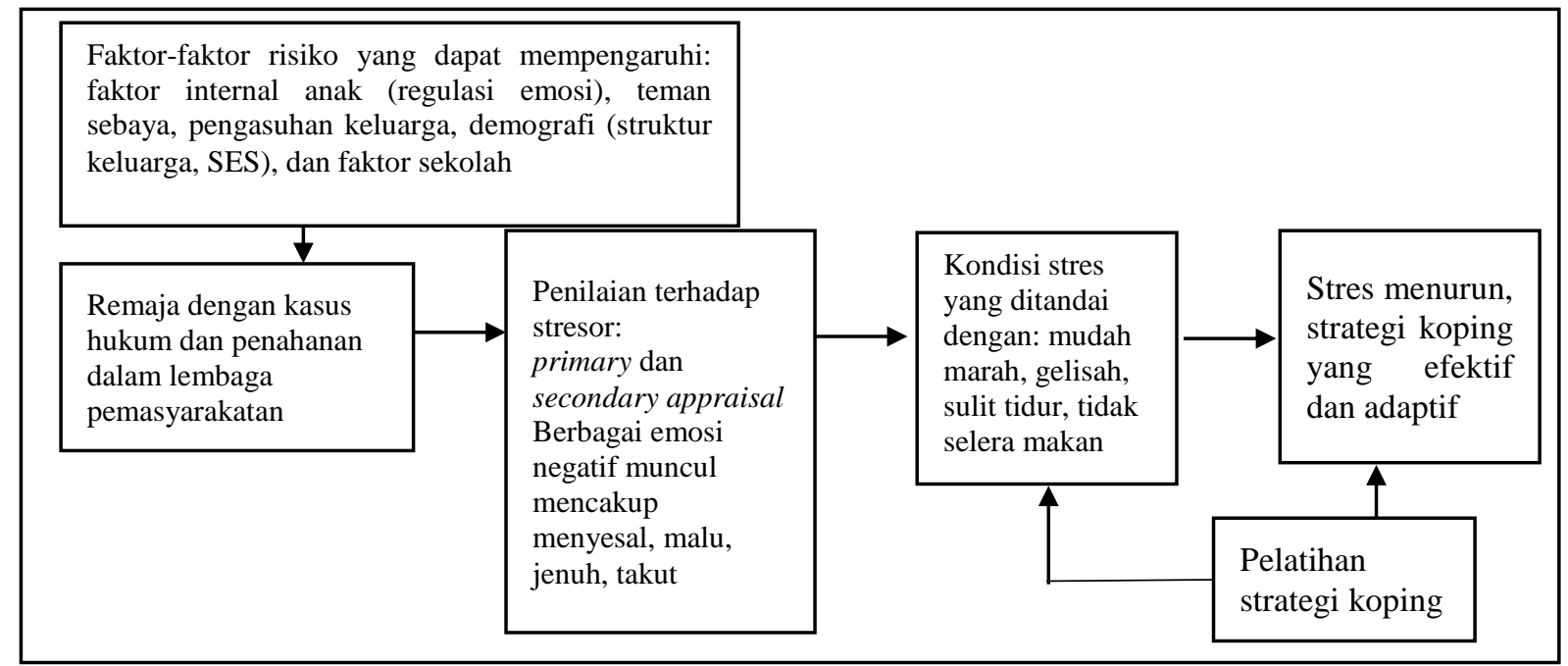

Gambar 1. Kerangka Berpikir

\section{METODE}

Subjek dalam penelitian ini merupakan 4 orang narapidana remaja dari 12 orang remaja yang telah memenuhi kriteria yaitu 1) Merupakan narapidana yang berada di Blok K (khusus remaja), 2) Menunjukkan kondisi stres dalam rentang sedang hingga berat berdasarkan skala stres DASS yang diberikan, 3) Setiap remaja akan diwawancarai untuk mengetahui motif, kronologi, serta latar belakang sebelum penahanan. Pemilihan sampel dilakukan dengan teknik purposive sampling (Neuman, 2014).

Penelitian ini merupakan penelitian kuasi eksperimen yang dilakukan untuk melihat pengaruh pelatihan strategi koping terhadap stres yang dialami narapidana remaja di lembaga pemasyarakatan (Lapas). Desain yang digunakan dalam penelitian ini adalah Non randomized one group pretest-post test design (Neuman, 2014). Adapun gambaran desainnya adalah sebagai berikut.

\section{\begin{tabular}{lll}
$\mathrm{O} 1$ & $\mathrm{X}$ & $\mathrm{O} 2$ \\
\hline
\end{tabular}}

Gambar 2. Gambaran Desain

Keterangan:

O1: Pretes tingkat stres narapidana remaja

$\mathrm{X}$ : Intervensi pelatihan strategi koping

O2: Post test tingkat stres narapidana remaja
Definisi operasional dalam penelitian ini adalah sebagai berikut.

a. Pelatihan strategi koping

Variabel bebas dalam penelitian ini adalah pelatihan strategi koping. Pelatihan strategi koping merupakan suatu pelatihan yang dirancang guna membantu narapidana remaja yang mengalami stres selama berada di lembaga pemasyarakatan. Pelatihan ini mencakup aspek pengetahuan terkait stres, emosi dan koping serta aspek keterampilan mengenai strategi koping berupa relaksasi dan latihan counting blessing. Pelatihan ini terdiri dari 8 sesi dengan gambaran pelaksanaan mencakup pembukaan, ice breaking, pemberian materi, permainan guess the emotion, latihan counting blessing, relaksasi dan evaluasi.

Pelaksanaan pelatihan dilakukan secara berkelompok yang terbagi dalam dua pertemuan dengan jarak pertemuan I dan II adalah satu hari. Modul pelatihan dirancang oleh penulis berdasarkan teori emosi (Ekman dalam Macklem, 2010) stres dan koping (Lazarus, 2006), yang telah di evaluasi oleh Psikolog serta Kepala Klinik Lembaga Pemasyarakatan terkait.

Penyusunan ini dilakukan dengan pertimbangan dari hasil studi pendahuluan yaitu 1) narapidana remaja belum menyadari 
kondisi emosinya, sehingga di awal wawancara menyampaikan kondisinya yang baik-baik saja kemudian secara tidak sadar menangis, menyatakan merasa stres, merasa bosan dan tidak dapat berpikir jernih. Pemahaman mengenai emosi dan stres diperlukan sehingga remaja dapat mengenali dan mengidentifikasi emosi-emosi yang dirasakan. 2) Narapidana remaja merasa sudah tidak memiliki peluang dan tidak dapat melakukan sesuatu sehingga merasa diri tidak mampu untuk menghadapi stresor yang dirasakan. Latihan counting blessing bertujuan untuk membantu subjek menemukan hal-hal positif yang dapat menjadi sumber daya koping baik internal maupun eksternal serta teknik relaksasi sederhana juga diberikan sebagai bentuk latihan yang dapat digunakan dalam menghadapi stresor yang dirasakan.

Pertimbangan lain dalam penyusunan modul dari penulis adalah latar belakang pendidikan dari keempat narapidana remaja yang putus sekolah sehingga penyusunan materi, latihan keterampilan dibuat sederhana, lebih singkat dan dipadukan dengan permainan-permainan.

b. Stres

Stres merupakan variabel terikat dalam penelitian ini. Stres merupakan suatu rangkaian reaksi dan proses fisiologis yang dihasilkan dari adanya tuntutan yang dinilai individu mengancam kesejahteraan diri dan individu merasa tidak memiliki sumber daya yang memadai untuk dapat menghadapi tuntutan tersebut. Skala stres yang digunakan dalam penelitian ini adalah skala stres dari DASS (Depression Anxiety Stress Scale) versi 42. Skala ini terdiri dari 14 item berbentuk Likert yang merupakan hasil translasi dari skala asli Lovibond dan Lovidond (1995) dengan koefisien reliabilitas 0,881 (Damanik, 2014). DASS disebutkan memiliki validitas dan reliabilitas yang baik pada populasi klinis dan non klinis di Indonesia. Skala ini terdiri skor penilaian $0,1,2$ dan 3 dengan kategori stres normal (0-14) hingga sangat berat (>34). Penelitian ini juga melibatkan wawancara dan evaluasi melalui pemberian lembar kerja yang diberikan pada sesi V (counting blessing).

Analisis data dalam penelitian ini berdasarkan pada data kuantitatif dan kualitatif. Analisis data kuantitatif yang bertujuan untuk menguji hipotesis penelitian dilakukan dengan menganalisis skor yang diperoleh dari skala stres menggunakan teknik Wilcoxon signed-ranks test guna melihat perbedaan tingkat stres pada narapidana remaja sebelum dan sesudah pemberian perlakuan. Data kualitatif diperoleh melalui hasil wawancara dan lembar kerja yang telah dikerjakan oleh subjek.

\section{HASIL DAN PEMBAHASAN}

Berdasarkan hasil wawancara, diperoleh data latar belakang dari keempat subjek dalam kelompok eksperimen.

Tabel 1

Data kelompok

\begin{tabular}{lcl}
\hline Subjek & Usia & \multicolumn{1}{c}{ Pelanggaran Hukum } \\
\hline DR & 16 tahun & $\begin{array}{l}\text { Pembunuhan, penodongan } \\
\text { dan pencurian }\end{array}$ \\
SY & 15 tahun & $\begin{array}{l}\text { Pembunuhan, penodongan } \\
\text { dan pencurian }\end{array}$ \\
ED & 18 tahun & $\begin{array}{l}\text { Pembunuhan } \\
\text { pencurian }\end{array}$ \\
BS & 17 tahun & Pelecehan seksual \\
\hline
\end{tabular}

Keempat subjek ini memiliki latar belakang yang relatif sama yaitu hubungan dengan keluarga yang kurang harmonis serta putus sekolah karena sering membolos dan bermasalah dengan guru. Sehari-hari keempat remaja ini menghabiskan waktunya dengan bermain game online di warnet, berkumpul bersama teman-teman dan minum-minuman keras. Faktor-faktor seperti hubungan dengan orangtua yang kurang baik, komunikasi yang buruk, pengasuhan yang kurang optimal serta faktor lain seperti kegagalan di sekolah disertai komitmen yang rendah terhadap sekolah menjadi faktor risiko dari kenakalan yang ditampilkan oleh remaja (Greenberg \& 
Lippold, 2013; Lee, Onifade, Teasley, \& Noel, 2012).

Berdasarkan uji hipotesis yang dilakukan, hasil uji analisis tersebut menunjukkan bahwa setelah pemberian perlakuan berupa pelatihan strategi koping, terdapat dua orang narapidana remaja yang mengalami penurunan stres (negative rank) dan dua orang remaja yang mengalami peningkatan stres (positive rank). Hasil perhitungan menunjukkan nilai signifikansi sebesar 0,465 $(p>0,05)$, hal ini berarti pelatihan strategi koping belum dapat secara signifikan menurunkan stres pada narapidana remaja.

Tabel 2

Hasil uji Wilcoxon signed rank test

\begin{tabular}{llcc}
\hline & & $\mathrm{N}$ & Mean Rank \\
\hline Pre- & Negative rank & 2 & 3.50 \\
post & Positive rank & 2 & 1.50 \\
& Z & & -0.730 \\
& Asymp. Sig. & & 0.465 \\
& (2-tailed) & & \\
\hline
\end{tabular}

Skor stres pada masing-masing subjek menunjukkan perubahan kategori stres pada subjek yang mengalami penurunan stres, namun pada subjek yang mengalami peningkatan skor stres masih berada dalam kategori yang sama.

Tabel 3

Kategori stres subjek pada pretest dan post test

\begin{tabular}{lll}
\hline \multirow{2}{*}{ Subjek } & \multicolumn{2}{c}{ Tingkat stres (DASS) } \\
\cline { 2 - 3 } & \multicolumn{1}{c}{ Pre } & \multicolumn{1}{c}{ Post } \\
DR & $25($ Moderate $)$ & $17($ Mild $)$ \\
SY & 19 (Moderate) & 21 (Moderate) \\
BS & $26($ Severe $)$ & $10($ Normal $)$ \\
ED & $26($ Severe $)$ & $29($ Severe $)$ \\
\hline
\end{tabular}

Terjadinya peningkatan skor stres pada dua orang subjek dapat dikaitkan dengan penilaian sumber daya koping internal yang cenderung negatif. Dua subjek yaitu ED dan SY menunjukkan bahwa dirinya tidak siap dan tidak mampu jika harus melewati hukuman yang lebih lama terlepas dari fakta mengenai pelanggaran hukum yang dilakukan.

"Ga terima, orang saya ga ikut ngabisin uangnya, kecewa kenapa dia bilang saya ikut ngabisin uang curiannya. Saya cuma nungguin aja disana, cuma ikut-ikutan aja, ngapain juga orang ga bersalah dibunuh... saya ga ke Karangasem (lapas anak) soalnya udah 18 tahun, jadinya hukumannya beda.." (ED, kasus pembunuhan dan pencurian)

"...saya lima tahun dapetnya, yang lain lebih ringan, harusnya tu saya di sekolah sekarang.... Ya tapi kan ga kayak gini juga hukumannya" (SY, kasus pembunuhan, penodongan dan pencurian)

Taylor \& Stanton (2007) menyebutkan bahwa salah satu sumber daya koping internal yang dapat membantu individu menghadapi stres adalah personal control yaitu sejauh mana individu merasa dirinya mampu untuk mengendalikan atau mempengaruhi dampak dari stresor, dalam hal ini ED dan SY sama-sama menunjukkan ketidakmampuan dalam menghadapi stresor tersebut. Sebuah studi pada narapidana remaja menunjukkan bahwa remaja memiliki kemungkinan yang lebih kecil untuk memproses kesusahan yang dialami di dalam penjara dengan cara yang menghasilkan pertumbuhan emosional (Newhard, 2014).

Pada subjek ED, surat keputusan vonis diperoleh tepat di hari pelaksanaan pelatihan, hal ini cukup mempengaruhi proses ED selama mengikuti pelatihan hingga selesai. ED mengaku sangat tertekan mengetahui bahwa dirinya mendapat vonis selama dua tahun atas tindakan pencurian, ED sangat kecewa dengan temannya yang dianggap memberikan kesaksian palsu dan melibatkan dirinya dalam kasus tersebut. Sedangkan pada subjek SY mengaku tidak 
sanggup melewati hukuman lebih lama dari teman dekatnya yang juga terlibat dalam kasus pembunuhan, meski bukti telah menunjukkan bahwa SY adalah pelaku penusukan dari pembunuhan yang dilakukan bersama teman-temannya.

Hal ini semakin mengkondisikan gejala stres sehingga stresor terasa semakin kuat. Stres dan koping menekankan pada persepsi individu terhadap kejadian yang menekan daripada kejadian itu sendiri dan hal ini menentukan sejauh mana strategi koping dapat dimunculkan dan apakah stresor dapat terselesaikan (Lazarus, 2006; Mohino, Kirchner, \& Forns, 2004).

Dua subjek lainnya yang mengalami penurunan tingkat stres yaitu DR dan BS, cenderung melihat bahwa hukuman penjara tidak seburuk yang dipikirkan, dan meyakini masih ada peluang positif jika nanti sudah menyelesaikan masa hukuman.

"...Ya ga apa, kan semua
dihukum ga cuma saya aja,
orang kita rame-rame ya jalanin
aja...nanti abis ini mau kerja"
(DR, kasus pembunuhan,
penodongan dan pencurian)
".. saya udah ikhlas, mbah juga
bilang ini cobaan, jadi harus
hati-hati sekarang, mikir dulu
sebelum bertindak gitu” (BS,
kasus pelecehan seksual)

Berdasarkan hasil lembar kerja pada sesi counting blessing, keempat subjek dapat menyebutkan hal-hal yang harusnya dapat disyukuri meskipun saat ini berada dalam Lapas. Secara umum keempat subjek merasa bersyukur memiliki orangtua yang memaafkan, perhatian dan bersedia melakukan segala upaya untuk membantu meski subjek sudah melakukan banyak kesalahan. Sebagian besar subjek menyesali dan mengakui perilakunya selama ini yang tidak menghargai orangtua, sering membantah dan pernah berkelahi serta mengarahkan golok ke arah ayahnya karena merasa kesal.
Teknik counting blessing yang diberikan memfokuskan pada evaluasi positif mengenai sumber daya koping, sehingga melalui munculnya rasa syukur terhadap hal yang telah dimiliki dan hal yang telah terjadi maka subjek dapat melakukan penilaian ulang terhadap situasinya terkait sumber daya koping yang dimiliki untuk menghadapi stresor.

Sumber daya koping merupakan sumber daya yang digunakan individu untuk dapat melakukan koping yang dapat berasal dari dalam diri individu ataupun dari luar diri individu (Barkway, 2013). Adapun keempat subjek sama-sama menilai bahwa dukungan sosial menjadi sumber daya koping utama mereka saat ini. Menurut Taylor dan Stanton, (2007), dukungan sosial sebagai sumber daya koping mencakup persepsi atau pengalaman dicintai, diperhatikan dari orang lain yang dinilai berharga untuk diri.

Melalui wawancara individual yang dilakukan, diketahui bahwa keempat subjek dapat menentukan strategi koping yang baru dan lebih efektif untuk dilakukan dalam melewati masa tahanan di dalam Lapas. Adapun strategi yang disebutkan mencakup menerima hukuman sebagai bentuk tanggung jawab akibat dari perbuatan, ingin lebih sering berdoa dan mengucap syukur pada Tuhan, serta menjadikan hukuman penjara sebagai memontum kesadaran bahwa perbuatan mencuri itu adalah kesalahan sehingga dapat menjadikan diri lebih baik dan berhati-hati dalam melakukan tindakan. Dua subjek juga mengungkapkan bahwa bercerita dengan teman narapidana dapat membantu mengurangi stres yang dirasakan. Menurut Lazarus (2006) reappraisal menjadi salah satu strategi koping yang efektif karena individu merubah emosi yang dirasakan dengan cara mengubah pandangan dan makna dari stresor yang sedang dihadapi.

Adapun latihan relaksasi pada keempat subjek disebutkan tidak dapat dilakukan secara mandiri di dalam blok 
karena situasi yang kurang kondusif dan tidak tenang. Berdasarkan hal tersebut, keempat subjek belum dapat mempraktikkan secara optimal salah satu keterampilan strategi koping yang bertujuan untuk menurunkan ketegangan yang dirasakan dan membantu ketika merasa kesulitan untuk tidur.

Relaksasi didefinisikan sebagai suatu kondisi pikiran dan otot yang tenang, ditandai dengan keadaan seperti penurunan tonus otot, serta detak jantung dan napas yang stabil (Macintyre, Rowbotham, \& Walker, 2008). Kondisi relaksasi tersebut akan lebih efektif pada situasi yang tenang sehingga strategi yang kemudian dilakukan peneliti adalah meminta subjek mencoba melakukan latihan relaksasi di tempat yang lebih tenang seperti tempat ibadah. Situasi di tempat ibadah cukup mendukung karena situasinya yang tidak terlalu ramai, dan meminimalisir kemungkinan terganggu oleh teman-teman di blok.

Berdasarkan pemaparan tersebut, meskipun pelatihan strategi koping yang diberikan tidak menunjukkan perubahan yang signifikan terhadap kondisi stres pada narapidana remaja, namun hasil evaluasi lembar kerja dan wawancara individual menunjukkan bahwa keempat subjek dapat menemukan cara koping yang lebih efektif dalam menghadapi situasi di dalam Lapas. Teknik counting blessing menjadi salah satu cara yang dapat membantu keempat subjek dalam melakukan penilaian ulang (reappraisal) secara positif terhadap pengalaman yang telah terjadi.

Keterbatasan dalam penelitian ini terkait dengan teknik keterampilan dalam modul intervensi yang kurang bervariasi dan belum mempertimbangkan kondisi di lapas sehingga terdapat kendala terkait latihan mempraktikkan relaksasi secara mandiri.

Selain itu, durasi pelatihan yang tergolong singkat yaitu 120-180 menit pada masing-masing pertemuan belum dapat memfasilitasi subjek untuk dapat menampilkan keterampilan strategi koping secara optimal karena membutuhkan evaluasi berkala dan berkelanjutan, terlebih lagi ketika vonis telah ditetapkan sebagian peserta akan dipindahkan ke lembaga pemasyarakatan anak.

Dinamika kondisi narapidana di lapas juga memberikan pengaruh terkait konsentrasi untuk mengikuti pelatihan, faktor-faktor yang mempengaruhi dapat berupa jadwal sidang, waktu penetapan vonis dan jadwal kunjungan keluarga. Terkait hal tersebut koordinasi dengan pihak-pihak di lembaga pemsyarakatan penting dilakukan sebelum menentukan jadwal pemberian perlakuan.

\section{SIMPULAN}

Berdasarkan hasil penelitian yang telah dilakukan, diperoleh simpulan bahwa secara kuantiatif pelatihan strategi koping tidak menunjukkan perubahan yang signifikan dalam menurunkan stres pada narapidana remaja. Pada keempat subjek, dua subjek mengalami penurunan tingkat stres, dua lainnya mengalami peningkatan tiga poin yang dipengaruhi faktor-faktor internal terkait penilaian terhadap sumber daya koping. Berdasarkan hasil wawancara individual, keempat subjek dapat menemukan suatu penilaian baru yang positif terhadap situasi di lapas dan menemukan strategi koping yang efektif yang dapat dilakukan oleh masingmasing subjek. Emotion-focused coping menjadi strategi koping yang lebih efektif berdasarkan situasi yang dihadapi oleh narapidana remaja terkait rendahnya kontrol terhadap dampak eksternal. Fokus terhadap sisi negatif disertai penolakan atas pengalaman menjadi faktor utama terhadap kondisi stres yang dirasakan oleh narapidana remaja.

Saran bagi peneliti selanjutnya adalah mempertimbangkan lebih lanjut faktor-faktor seperti jadwal sidang dan jadwal kunjungan keluarga dari narapidana remaja dalam menentukan waktu pelaksanaan, hal ini turut mempengaruhi kondisi remaja ketika terlibat 
dalam suatu intervensi. Saran lainnya berkaitan dengan pemilihan teknik-teknik stategi koping lain yang dapat menyesuaikan dengan situasi di lapas, hal ini agar teknik yang diberikan dapat terapkan secara mandiri oleh narapidana remaja.

\section{DAFTAR PUSTAKA}

Barkway, P. (2013). Psychology for health professionals $\left(2^{\text {nd }} \mathrm{Ed}\right.$.). Sidney: Elsevier Inc.

Beauchaine, T. P., \& Hinshaw, S. P. (2013). Child and adolescent psychopathology ( $2^{\text {nd }}$ Ed.). New Jersey: John Wiley \& Sons, Inc.

Damanik, E. (2014). Damanik translation Bahasa Indonesia: Depression Anxiety Stress Scales (DASS) dalam Psychology Foundation of Australia. Retrieved from http://www2.psy.unsw.edu.au/ dass/DASSFAQ.htm

Greenberg, M. T., \& Lippold, M. A. (2013). Promoting healthy outcomes among youth with multiple risks: Innovative approaches. The Annual Review of Public Health, 34, 253-270.

Hashemi, F., Darshori, A. F., Sharif, F., Karimi, M., \& Zare, N. (2015). Effect of coping strategies training on its use by thalassemia major adolescents: A randomized controlled clinical trial. IJCBNM, 3(1), 67-74.

Houghton, J. D., Godwin, J. L., Neck, C. P., \& Manz, C. C. (2012). Effective stress management: A model of emotional intelligence, self-leadership, and student coping stress. Journal of Management Education, 36(2), 220-238.

Jones, C., \& Nonas-Barnes, L. (2017). Effectiveness of skills groups for adolescents in correctional settings: A scientific systemic review. Columbia Social Work Review, 8, 1-5.

Institute for Criminal Justice Reform. (2017). Problem implementasi sistem peradilan pidana anak di indonesia masih ditemukan. Retrieved from http://icjr.or.id/problem-implementasisistem-peradilan-pidana-anak-diindonesia-masih-ditemukan/

Lazarus, R. S. (2006). Stress and emotion: A new synthesis. New York: Springer Publishing Company.

Lee, J., Onifade, E., Teasley, M., \& Noel, L. (2012). The effect of risk and protective factors on juvenile deliquency in south korea. Journal of Etnicity in Criminal Justice, 10, 316-329.

Lerner, R. M., \& Steinberg, L. D. (2004). Handbook of adolescent psychology. USA: John Wiley \& Sons, Inc.

Lovibond, P. F., \& Lovidond, S. H. (1995). The structure of negative emotional state: comparison of Depression Anxiety Stress Scale (DASS) with The Beck Depression and Anxiety Inventories. Behavior Reseach Theory, 33(3).

Macintyre, P., Rowbotham, D., \& Walker, S. (2008). Clinical pain management: Acute pain (2nd Ed.). London: Hodder Education.

Macklem, G. L. (2010). Evidence-based school mental health services: Affect education, emotion regulation training, and cognitive behavioral therapy. Boston: Springer Science \& Business Media.

Mansoor, M., Perwez, S. K., Swamy, T. N. V. R., \& Ramaseshan, H. (2015). A critical review on role of prison environment on stress and psychiatric problems among prisoners. Mediterranean Journal of Social Sciences, 6(1), 218-223.

Mohino, S., Kirchner, T., \& Forns, M. (2004). Coping strategies in young male prisoners. Journal of Youth and Adolescence, 33(1), 41-49.

Neuman, W. L. (2014). Social research methods: Qualitative and quantitative 
approach $\left(7^{\text {th }}\right.$ Ed). Edinburgh: Pearson Education Limited.

Newhard, J. R. (2014). Coping responses and mental health symptoms in incarcerated juvenile males. Dissertation, Antioch University.

Papalia, D. E., Old, S. W., \& Feldman, R. D. (2008). Human Development (Psikologi Perkembangan) (Edisi Ke-9). Jakarta: Kencana.

Porter, L. C. (2018). Being "on point": Exploring the stress-related experiences of incarceration. American Sociological Association, 9(1), 1-17.

Shulman, E. P., \& Cauffman, E. (2012). Coping while incarcerated: A study of male juvenile offenders. $J$ Resc Adolesc, 21(4), 818-826.
Siegel, L. J., \& Welsh, B. C. (2018). Juvenile deliquency: Theory, practice, and law $\left(13^{\text {th }}\right.$ Ed.). Boston: Cengage Learning.

Talik, E., \& Skowronski, B. (2018). The sense of quality of life and religious strategies of coping with stress in prison inmates. Journal Religious Health, 57, 915-937.

Taylor, S. E., \& Stanton, A. L. (2007). Coping resources, coping processes, and mental health. Annual Review Clinical Psychology, 3, 377-401.

Vitulic, H. S., \& Prosen, S. (2015). Coping and emotion regulation strategies in adulthood: Specifities regarding age, gender, and level of education. Journal for General Social Issues, 25(1), 43-62.

Wilmshurst, L. (2015). Essentials of child and adolescent psychopathology ( $2^{\text {nd }}$ Ed.). New Jersey: Wiley \& Sons, Inc. 